DOI: $10.30525 / 978-9934-588-61-7-28$

Cherchel V. Yu.

Doctor of Agricultural Sciences, Senior Research Fellow,

Director,

SE Institute of Grain Crops of National Academy

of Agrarian Sciences of Ukraine

Kompaniets V. $O$.

Candidate of Economic Sciences, Senior Research Fellow,

Head of the Laboratory of Economics,

SE Institute of Grain Crops of National Academy

of Agrarian Sciences of Ukraine

Kulik A. O.

Chief Specialist of the Laboratory of Economics,

SE Institute of Grain Crops of National Academy

of Agrarian Sciences of Ukraine

\title{
STRATEGY OF GRAIN PRODUCTION DEVELOPMENT IN THE STEPPE ZONE OF UKRAINE
}

\section{Summary}

The article is devoted to the problem of increasing efficiency of the grain sector of the Steppe zone of Ukraine. According to the results of the research, the trends in the development of grain production in the agricultural enterprises of the Steppe zone of Ukraine, concerning to the dynamics of harvested areas, yields and gross harvests of grain crops, are elucidated. Dynamic changes in the profitability of grain production are analyzed. The main directions of increasing the efficiency of grain production and its competitiveness are formulated. On the base of results of the analysis, experimental experience of SE Institute of Grain Crops of NAAS and expert assessments, two models of grain production in the Steppe zone of Ukraine for levels of 26.3 and 35.0 million tons are elaborated. The perspective sizes of the harvested areas, grain crops acreage structure and the levels of yield and gross harvests of grain crops are grounded. The requirement for production resources is calculated, and the level of efficiency of grain production in the agrarian formations of the Steppe zone of Ukraine for the future is forecasted.

\section{Introduction}

Grain production is one of the factors ensuring sustainable development of the country's economy, as it is an important source of formation of gross national product and value added. Today, we can testify to the unresolved problem of achieving a high level of efficiency of a grain sector, in particular, the grain production of the Steppe zone of Ukraine. It is obvious that total political and socio-economic crisis has negatively affected the development of 
grain farming both at the level of the state and regions, and at the level of each agricultural producer.

Nowadays, not only the domestic but also the world economy is beginning to change its format under the influence of growing global shocks, which will touch all areas of human life soon. Our country's agriculture will once again be forced to operate in the conditions of a severe financial and economic crisis, but it is evident that this crisis may become even more severe than it has been in the 1990s. Therefore, the previously identified strategic directions for the development of the grain sector need to be adjusted both at the state level and the level of natural-economic zones and regions.

Scientific and methodological issues of efficiency of grain production, problems of theory and practice of its intensification are embodied in the works of A. Babych-Poberezhna, O. Bodnar, V. Boiko, P. Haidutskyi, K. Horpinchenko [1], O. Zakharchuk, L. Kurilo, A. Lysetskyi, M. Lobas, N. Liashenko [2], Z. Nikolaieva, H. Maslov [3, 4], A. Prudnikov [1], P. Sabluk [5, 6], V. Saiko, L. Khudolii, O. Shpychak [7] and others. A significant contribution to the study of effectiveness of the application of scientifically grounded technologies for growing grain crops in the Steppe zone of Ukraine has been made by scientists of SE Institute of Grain Crops of NAAS, such as M. Kirpa, E. Lebid, F. Lorinets, V. Nesterets, I. Pabat, M. Solodushko, A. Cherenkov [8], M. Shevchenko [9] etc.

Today, the scientific research in the direction of increasing efficiency of the grain sector continues. On the one hand, in the context of development of the agrarian innovations market, improvement of technical and technological characteristics of the process of growing crops and grain legume, there is a need to deepen the research to ground the directions of effective development of grain production in the Steppe zone of Ukraine. On the other hand, modern realities of life dictate the growing need for adaptive technologies that allow to achieve maximum cost savings of production resources per hectare of sown area and maintenance of ecological safety requirements.

The purpose of this article is to ground the strategic directions of grain production in the Steppe zone of Ukraine.

The information base of the research has been data of the State Statistics Service of Ukraine, reports on implementation of the research programs of SE Institute of Grain Crops of NAAS, reference, normative materials and also theoretical, practical and methodological works of domestic and foreign science [1-12].

\section{Part 1. The current state of development of grain production and its efficiency in the agricultural enterprises of the Steppe zone of Ukraine}

The study of the zonal peculiarities of grain production location has shown that the Steppe zone is a leader in the grain sector of Ukraine because for the past 10 years its share has accounted for $44.5-49.7 \%$ of the harvested area of grain crops. However, due to the presence of a large number of limiting natural and climatic factors, the yield potential of grain crops in the Steppe zone is realized on average 30-50\% worse than in the Forest-Steppe, so the Steppe zone accounts for only a third of gross national grain production. 
The results of the retrospective analysis have shown that the dynamics of indicators of harvesting areas, yields and gross grain harvests were characterized by significant instability over the years. Orientation toward intensification and industrialization of agricultural production in the 1980s provided in Ukraine the gather of grain from 35-40 to 50-53 million tons annually. The economic crisis, which enveloped the agricultural sector of economy in the 1990s, negatively affected the level of material and technical, and financial maintenance of agricultural producers, conditioned massive violations in the technology of growing crops and, of course, led to a reduction in their yields and shortening dimensions of grain production. Thus, for 1996-2000 (with the exception of 1997), annual grain harvests in Ukraine ranged within the confines of 24-26 million tons. For the past decade, the mark of 60 million tons of grain has been overcome seven times during 20132019. In particular, during the past two years, gross grain production has reached record levels of 70.1 and 75.1 million tons.

The situation was similar (Table 1-3) in the Steppe zone of Ukraine for most years, but it should be noted that a record 25 million tons of grain were obtained only twice in 1989 and 2019. For the past 35 years, gross harvests of 23-24 million tons were received in 1988, 1990, 2008, and 20-22 million tons of grains were gathered in 1987, 1993, 2001, 2004 and for 2013-2018.

Table 1

Harvested areas of grain crops in the Steppe zone of Ukraine, thousand hectares

\begin{tabular}{|c|c|c|c|c|c|c|c|c|}
\hline \multirow[b]{2}{*}{ Years } & \multirow{2}{*}{$\begin{array}{c}\text { Grain } \\
\text { crops } \\
\text { total } \\
\end{array}$} & \multicolumn{7}{|c|}{ including } \\
\hline & & $\begin{array}{l}\text { winter } \\
\text { wheat }\end{array}$ & $\begin{array}{l}\text { winter } \\
\text { barley }\end{array}$ & $\begin{array}{c}\text { winter } \\
\text { rye }\end{array}$ & $\begin{array}{l}\text { grain } \\
\text { maize }\end{array}$ & $\begin{array}{l}\text { spring } \\
\text { barley }\end{array}$ & oat & $\begin{array}{c}\text { grain } \\
\text { legume }\end{array}$ \\
\hline 2001 & 7178.6 & 3669.9 & 450.1 & 224.8 & 536.9 & 1700.7 & 146.5 & 99.3 \\
\hline $2001-2005$ & 6750.3 & 2881.5 & 380.6 & 117.9 & 763.0 & 2034.6 & 107.3 & 130.7 \\
\hline 2006-2010 & 7093.5 & 3318.5 & 794.4 & 37.3 & 682.2 & 1840.9 & 58.9 & 139.5 \\
\hline 2011 & 7472.4 & 3565.9 & 1024.3 & 26.5 & 1067.4 & 1305.6 & 41.7 & 161.8 \\
\hline 2012 & 6798.5 & 2813.8 & 514.9 & 23.2 & 1367.7 & 1507.1 & 55 & 166.1 \\
\hline 2013 & 7582.3 & 3661.4 & 889.6 & 24.6 & 1346.5 & 1223.1 & 47.7 & 137.0 \\
\hline 2014 & 6777.0 & 3251.0 & 898.9 & 18.1 & 1292.1 & 987.2 & 37.9 & 93.4 \\
\hline 2015 & 6793.4 & 3562.3 & 867.1 & 14.4 & 1134.2 & 909.6 & 25.3 & 102.8 \\
\hline 2011-2015 & 7084.7 & 3370.9 & 839.0 & 21.4 & 1241.6 & 1186.5 & 41.5 & 132.2 \\
\hline 2016 & 6401.0 & 2999.2 & 796.7 & 9.5 & 1226.7 & 1001.4 & 22.6 & 144.6 \\
\hline 2017 & 6623.3 & 3373.5 & 724.8 & 12.0 & 1235.6 & 858.9 & 18.6 & 235.3 \\
\hline 2018 & 6652.2 & 3567.5 & 723.7 & 11.2 & 1144.5 & 789.9 & 16.0 & 271.6 \\
\hline 2019 & 6804.2 & 3708.0 & 861.5 & 9.4 & 1157.5 & 723.3 & 13.3 & 190.4 \\
\hline $\begin{array}{l}2019 \text { to } \\
2001, \%\end{array}$ & 94.8 & 101.0 & 191.4 & 4.2 & 215.6 & 42.5 & 9.1 & 191.7 \\
\hline
\end{tabular}

Source: conducted by the authors on the data basis of the State Statistics Service of Ukraine 
Table 2

Yield of grain crops in the Steppe zone of Ukraine, tons per hectare

\begin{tabular}{|c|c|c|c|c|c|c|c|c|}
\hline & Grain & \multicolumn{7}{|c|}{ including } \\
\cline { 3 - 9 } Years & total & $\begin{array}{c}\text { winter } \\
\text { wheat }\end{array}$ & $\begin{array}{c}\text { winter } \\
\text { barley }\end{array}$ & $\begin{array}{c}\text { winter } \\
\text { rye }\end{array}$ & $\begin{array}{c}\text { grain } \\
\text { maize }\end{array}$ & $\begin{array}{c}\text { spring } \\
\text { barley }\end{array}$ & oat & $\begin{array}{c}\text { grain } \\
\text { legume }\end{array}$ \\
\hline 2001 & 2.95 & 3.45 & 2.92 & 2.48 & 2.67 & 2.53 & 2.00 & 2.18 \\
\hline $\mathbf{2 0 0 1 - 2 0 0 5}$ & $\mathbf{2 . 5 2}$ & $\mathbf{2 . 9 6}$ & $\mathbf{2 . 5 7}$ & $\mathbf{2 . 1 6}$ & $\mathbf{3 . 1 3}$ & $\mathbf{1 . 9 7}$ & $\mathbf{1 . 7 7}$ & $\mathbf{1 . 6 4}$ \\
\hline $\mathbf{2 0 0 6 - 2 0 1 0}$ & $\mathbf{2 . 4 5}$ & $\mathbf{2 . 7 4}$ & $\mathbf{2 . 4 6}$ & $\mathbf{2 . 0 3}$ & $\mathbf{3 . 1 5}$ & $\mathbf{1 . 8 6}$ & $\mathbf{1 . 5 3}$ & $\mathbf{1 . 6 1}$ \\
\hline 2011 & 3.06 & 3.18 & 2.64 & 2.10 & 4.87 & 2.08 & 1.73 & 1.35 \\
\hline 2012 & 1.93 & 1.98 & 1.53 & 1.69 & 2.63 & 1.56 & 1.58 & 1.24 \\
\hline 2013 & 2.91 & 2.86 & 2.55 & 2.19 & 4.72 & 1.68 & 1.39 & 1.20 \\
\hline 2014 & 3.17 & 3.41 & 2.87 & 2.37 & 3.75 & 2.29 & 2.08 & 1.93 \\
\hline 2015 & 3.16 & 3.31 & 2.85 & 2.33 & 3.93 & 2.26 & 1.59 & 1.87 \\
\hline $\mathbf{2 0 1 1 - 2 0 1 5}$ & $\mathbf{2 . 8 5}$ & $\mathbf{2 . 9 8}$ & $\mathbf{2 . 5 8}$ & $\mathbf{2 . 1 1}$ & $\mathbf{3 . 9 4}$ & $\mathbf{1 . 9 3}$ & $\mathbf{1 . 6 6}$ & $\mathbf{1 . 4 5}$ \\
\hline 2016 & 3.48 & 3.60 & 3.33 & 2.64 & 4.29 & 2.56 & 2.45 & 2.91 \\
\hline 2017 & 3.32 & 3.62 & 3.15 & 2.69 & 3.49 & 2.61 & 2.11 & 2.13 \\
\hline 2018 & 3.19 & 3.11 & 3.11 & 2.15 & 4.99 & 1.87 & 1.41 & 1.21 \\
\hline 2019 & 3.68 & 3.58 & 3.41 & 2.60 & 5.30 & 2.61 & 1.87 & 2.00 \\
\hline $\mathbf{2 0 1 9}$ to & $\mathbf{1 2 4 . 6}$ & $\mathbf{1 0 3 . 7}$ & $\mathbf{1 1 6 . 7}$ & $\mathbf{1 0 4 . 5}$ & $\mathbf{1 9 8 . 3}$ & $\mathbf{1 0 3 . 1}$ & $\mathbf{9 3 . 5}$ & $\mathbf{9 1 . 6}$ \\
$\mathbf{2 0 0 1 , \%}$ & & & & & & & & \\
\hline
\end{tabular}

Source: conducted by the authors on the data basis of the State Statistics Service of Ukraine

Table 3

Gross harvest of grain crops in the Steppe zone of Ukraine, thousand tons

\begin{tabular}{|c|c|c|c|c|c|c|c|c|}
\hline \multirow[b]{2}{*}{ Years } & \multirow{2}{*}{$\begin{array}{c}\text { Grain } \\
\text { crops } \\
\text { total }\end{array}$} & \multicolumn{7}{|c|}{ including } \\
\hline & & $\begin{array}{l}\text { winter } \\
\text { wheat }\end{array}$ & $\begin{array}{l}\text { inter } \\
\text { arley }\end{array}$ & $\begin{array}{c}\text { winter } \\
\text { rye }\end{array}$ & $\begin{array}{l}\text { grain } \\
\text { maize }\end{array}$ & $\begin{array}{l}\text { spring } \\
\text { barley }\end{array}$ & oat & $\begin{array}{c}\text { grain } \\
\text { legume }\end{array}$ \\
\hline 200 & 212 & 12660.3 & & 558.3 & & 4311.1 & 293.6 & 216.1 \\
\hline & 989.2 & 20.9 & 979.0 & 254.6 & 390.9 & 3999.1 & 190.2 & 214.3 \\
\hline $\begin{array}{c}2006- \\
2010\end{array}$ & 17393.4 & 8 & 1957.0 & 75.6 & 0 & 5 & 90.0 & 2 \\
\hline & & & & 50 & & & & \\
\hline & & & & & & & D & \\
\hline & & & & & & & & \\
\hline & & & & 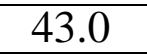 & & & 78.9 & \\
\hline 20 & 2144 & 117 & 247 & 33.6 & & 20 & 40.1 & 192.5 \\
\hline $\begin{array}{r}201 \\
201 \\
\end{array}$ & $\mathbf{0}$ & 10 & 4 & 45.1 & 4889.1 & .8 & 68.9 & 192.4 \\
\hline & & & & & & & 523 & \\
\hline 20 & & & & 32 & & 22 & 39.2 & .1 \\
\hline 20 & & & & 24.1 & & 14 & 22.5 & 328.4 \\
\hline & 7 & 132 & 293 & 24.4 & & 1885.8 & 24.9 & 380.1 \\
\hline $\begin{array}{r}2019 \text { to } \\
2001, \%\end{array}$ & 118.0 & 104.8 & 22 & 4. & 42 & 43.7 & 8 & 175.9 \\
\hline
\end{tabular}

Source: conducted by the authors on the data basis of the State Statistics Service of Ukraine 
It has been established that the gross harvest of grain crops of Ukraine (including the Steppe zone) was formed by growing three main crops, such as winter wheat, spring barley and maize. Until 2010, the priority crop was exclusively winter wheat, and, secondly, there was spring barley. Nevertheless, starting from 2011-2012, the focus on market demand has led to a decrease of spring barley sowings and a sharp expansion of maize acreage.

The analysis of the dynamics of the harvested areas of grain crops in the agricultural formations of the Steppe zone for 1986-2019 has shown a tendency to their reduction due to the expansion of industrial crops acreage (sunflower sowings). The rate of reduction was the greatest in the period 1990-2000, especially concerning maize. For the past three years, there has been shaped a trend to stabilize the harvested area of winter wheat at 3.4-3.7 million hectares with a parallel expansion of the maize acreage to 1.1-1.2 million hectares and reducing the harvested area of spring barley to $0.7-0.9$ million hectares.

In the Steppe zone, which is considered a zone of risky agriculture, for the last 15 years, the average yield in the group of grain crops and grain legume was lower than in Ukraine by $2.5-38.1 \%$. The dynamic changes in the yield of major grain crops were characterized by a significant range of fluctuations. Thus, the minimum value of grain crops and grain legume yields in the Steppe zone was $1.63 \mathrm{t} / \mathrm{ha}$ in 2007 , and the maximum value was $3.68 \mathrm{t} / \mathrm{ha}$ in 2019 . The best natural and economic conditions for growing grain crops took shape in the Forest-Steppe zone, where the maximum yield in 2018 was 6.18 t/ha. In this zone, accordingly, there was a larger scope of variation. In Polissia, the level of grain crops productivity during the studied period varied in the range from 2.28 (2006) to 5.61 (2019) t/ha, and in Ukraine it varied from 2.18 (2007) to $4.91 \mathrm{t} / \mathrm{ha}$ (2019).

The data of Table 3 show that during the period 2001-2019 there has been an increase in the level of yield on the most grain crops with growth rates from $103.7 \%$ for winter wheat to $198.3 \%$ for maize.

In the recent years, there has been a positive trend in the action of factors of increasing grain yields, which can be attributed to a rational use of soil and climatic resources, an introduction of high-yielding varieties (hybrids), pest control, etc. On the other hand, it should be taken into account the increase in grain production by large companies that have necessary resources for growing grain crops on an intensive basis.

However, it should be noted that the growth of grain productivity, which we observe in recent years, should be considered not only as a result of action of natural, organizational and technological factors. Largely, it is a result of structural changes in the grain crops acreage connected with expanding maize sowing areas with the relatively higher yield potential of modern hybrids and parallel reduction of the areas under less yielding spring barley, oats, millet, etc.

It is established that instability of gross grain harvests causes uneven intensity of filling the market with grain products and, ultimately, has a negative impact on market conjuncture and profitability of the sector. Therefore, for the farms of the Steppe zone, the urgent problem is a search and implementation of the reserves to increase a productivity of grain crops, as well as improving their territorial location with the parallel implementation of measures to enhance ecological efficiency of production. 


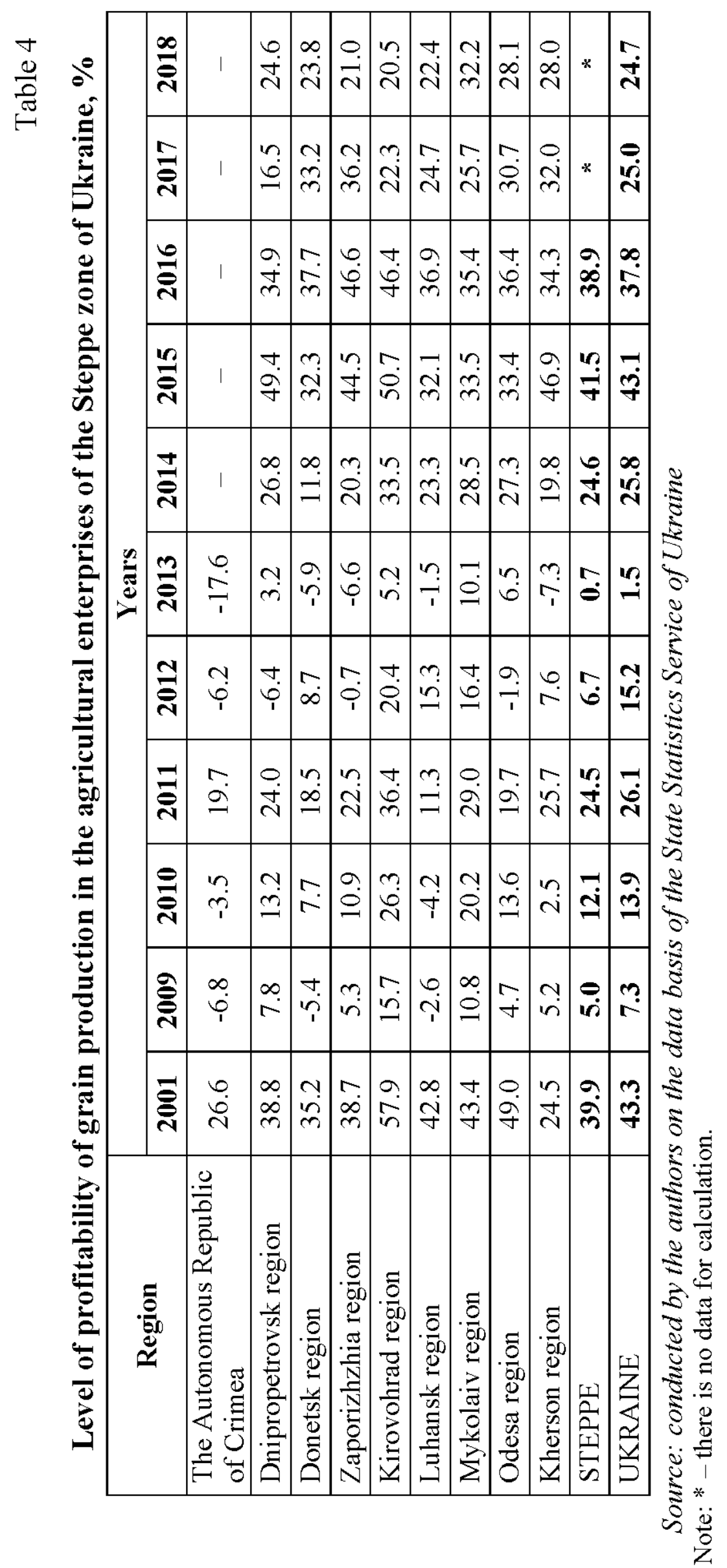


The results of the analysis for the period from 2001 to 2018 (Table 4) demonstrate a variety of indicators of profitability of grain production by the years depending on the level of technological efficiency of the sector and the price situation in the grain market. At the same time, there is a negative trend of lagging the profitability indicators achieved in the farms of the Steppe zone of Ukraine, in comparison with the average level in Ukraine. Thus, the highest level of profitability in Ukraine was achieved in 2001 (43.3\%), and in the Steppe zone it was reached value $41.5 \%$ in 2015 . Unfortunately, due to narrowing the range of indicators of official statistical reporting for 2017-2018, the calculation of the average level of profitability in the Steppe zone is not considered possible. The lowest profitability indicators were formed in the conditions of unfavorable price situation in 2013. The average profitability of grain production in Ukraine was $1.5 \%$, and in the Steppe zone it achieved only $0.7 \%$.

\section{Part 2. The main directions of increasing efficiency of the grain sector of the Steppe zone of Ukraine}

Transformation processes in the grain sector in a total socio-economic crisis require deepening the research to improve the concept of solving the grain problem, which should be adequate to modern conditions and contain a set of measures to overcome the crisis and lead grain production to a competitive level. In particular, it is necessary to outline the main directions of improving efficiency of the grain sector of the Steppe zone, such as:

- to improve land use based on the optimization of agricultural landscapes, which provides for the withdrawal from agricultural turnover of eroded and unproductive lands. The results of our previous studies [11] have shown that on lands that should remain in intensive cultivation, it is necessary to radically change the structure of sown areas in crop rotations and introduce ecologically balanced farming systems to improve soil fertility. Arranging land resources based on the movement of bare fallows from the slopes to the plain areas with the most fertile soils and increasing the proportion of perennial grasses will allow to protect the soil from water and wind erosion during the year, provide regulation of humus balance, increase the inflow of available nutrients into the soil, reduce machines load on the ground, decrease labor and money-material expenditures per unit of final product by reducing annual operations related to soil treatment and sowing, introduce a large-strip location of crops (bare fallows are on the plain and perennial grasses are on the slope), which will provide better conditions for the application of contour tillage, differentiated fertilizer system, taking into account the erosion degree of soil.

Withdrawal of sloping lands from intensive cultivation, displacement of bare fallows and the least effective in terms of soil protection the tilled crops (maize, sunflower, etc.) on a plain and slopes up to $1^{0}$ will allow to significantly reduce erosion processes and thus improve conditions of the ecological balance of the environment. Sowing perennial grasses, especially legumes, will allow to increase the fertility of eroded soils and their 
productivity, as well as creating a strong resources base for livestock and whole agricultural production;

- to optimize the crop rotation system. Long-term experimental data of SE Institute of Grain Crops of NAAS [12] confirm the positive effect of the fallow on the water balance and phytosanitary condition of the crop rotation in general, so in the structure of the rotation area it is advisable to allocate 5$10 \%$ for black fallow in the northern Steppe, 10-15\% in the central and 15$20 \%$ in the southern Steppe. In farms specializing in the cultivation of marketable and fodder grain, it is advisable in the structure of rotation area to occupy up to $60 \%$ by grain crops and $30-40 \%$ by fodder crops. In small farms, it is recommended to introduce the short-term rotations with a share of grain crops up to $75-80 \%$.

Construction of the optimal model of crop rotations, farming system and ratio of crops in the structure of sown areas of the Steppe zone of Ukraine in the current situation should take into account ecological requirements and be based on the newest agricultural technologies and varieties (hybrids) of cultivated crops, effective plant protection system and economic expediency of production activity;

- to develop and implement a set of measures for land reclamation and environmental protection;

- to develop the adaptive and scientifically ground, economically and ecologically efficient regional farming systems;

- to create the necessary organizational and territorial conditions for effective use of material, technical and labor resources, an introduction of innovative technologies of crop cultivation and progressive methods of agrarian production management;

- to improve the system of agrochemical support of grain production focused on achieving a high level of efficiency of applying organic, organomineral and bioactive fertilizers (including the use of green fertilizers and by-products of crop production, biological products of complex action, composting waste products of livestock and poultry breeding, etc.), achieving a deficit-free balance of humus in the soils of Ukraine, as well as the production of high quality and eco-friendly products. Fertilizer application should be carried out in the most effective ways, taking into account the results of agrochemical examination of soils and plant diagnostics. In modern times, it is topicality to carry out the transition from traditional methods of fertilizer application to innovative technologies based on modern software and technical means in order to improve soil fertility management and product quality;

- to introduce the innovative adaptive technologies of grain crops cultivation based on the use of modern domestic varieties (hybrids) with a high potential for yield and grain quality, and also the use of advanced technical means. Modern technical and technological support of grain production should be focused on creating conditions not only to obtain the maximum quantity of products per unit area, but also to adhere to ecological safety requirements concerning to use of land and other production resources 
(prevention of environmental pollution, violation of ecological balance in agribiocenoses, soils degradation, etc.), as well as obtaining eco-friendly products of high quality;

- to develop and implement the efficient energy and resource-saving technologies with elements of biologization, including use of zero-tillage technologies on suitable soils, etc.;

- to introduce an integrated system of grain crops protection, which is based on the rational use of organizational and economic, agro-technical, chemical, biological and other measures. In the future, the priority direction should be the biologization of grain production based on the use of the newest biological means (biofungicides, bioherbicides, bioinsecticides, etc.) and reducing the chemical load per hectare of acreage;

- to optimize the production expenditures per hectare of sown area in order to achieve a high level of payback of outlays and obtain the largest amount of profit from 1 ha by preventing unproductive losses, cost saving by improving an organization of the technological process and improving use of human capacity, resource and energy savings, applying agrotechnical measures of plant protection taking into account the harmfulness of pathogenic organisms, introduction of methods of precision farming based on innovative technical means, optimization of overhead, etc.

Achieving the goals of resource and energy saving can be ensured through a combination of technological operations, use of universal mobile energy means and ultra-small spraying sown areas of crops, optimization of the choice (combination) of direct and pick-up combining during harvesting, etc. [4];

- to implement the gradual technical and technological re-equipment of the grain sector on the basis of science-intensive technologies and highproductive technical means of a new generation of domestic and foreign production;

- to improve the technical support of grain production on the basis of optimization of machine-tractor park composition, introduction of multifunctional units, improvement of organization of mechanized works, increasing the quality of works due to introduction of the measures to prevent losses and damages of grain, ensuring the accordance to ecological safety requirements, introduction of precision agriculture methods, etc. [3].

- to implement the progressive forms of technical means operation, in particular, development of the system of their inter-farm use on the basis of establishing technical centers, and also cooperative, private and other structures which will provide high-quality technical services;

- to develop the domestic system of selection and seed production. Introduction of new high-yielding, more resistant to adverse weather and climatic conditions and diseases varieties (hybrids), renewal of elite seeds and seeds of high generations allows to increase the level of productivity of grain crops from 20-25 to 30-35\%. The choice of specific varieties or hybrids should be based on the recommendations of regional research institutions, regional state centers for examination of plant varieties and varietal research 
stations. The state must provide sufficient funding for state support programs for breeding and seed production;

- to develop the systems for post-harvest processing grain, its storage and transportation;

- to form effective systems of standardization, certification and quality control of grain;

- to improve the infrastructure of innovation activity on the basis of expansion of production and technical structure, improvement of personnel and educational structure, development of sales, consulting and informationanalytical organizations, financial structures [1];

- to improve the system of state management of the innovation process in grain production on the basis of an application of economic, organizational and lawful measures to regulate the management of the innovation process, creating special financial instruments for state support of innovation activity, expanding mechanisms for updating the technical base of the innovation process [1];

- to develop the grain market infrastructure, improvement of grain market monitoring system;

- to improve the system of state regulation of a grain market and supporting the domestic grain producer, that is aimed at solving the problem of ensuring the equivalence of inter-sector exchange in agro-industrial complex and enhancing the interest of agricultural formations to increase production of high quality grain products;

- to develop the grain processing within the country, improvement of the mechanism of sale of grain and products of its processing on the foreign market, etc.

Significant reserves for improving the efficiency of grain production, rising the income of grain producers and increasing foreign exchange earnings are in stimulating the promotion of grain products on the foreign market. However, in this regard, it is worth emphasizing the necessity to optimize the proportions of the distribution of crop products for export and processing. In particular, concerning to grain, which Ukraine currently actively exports to the world market, state priorities should be shifted in favor of expanding its processing within the country (including further export of processed products), which will not only be an additional source of added value, but also additional jobs. Considering the importance of this problem, the state should use leverages to properly adjust this issue concerning both grain and other crop products.

\section{Part 3. Perspective parameters of grain production in the Steppe zone of Ukraine}

On condition of overcoming the crisis and improving the structure of the grain acreage, it is possible to stabilize the annual grain production in Ukraine at the level of 70-75 million tons and reach 80-100 million tons in the distant perspective [3]. 
On the basis of the research results and the literature sources used in the article, as well as taking into account the expert assessments of scientists of SE Institute of Grain Crops of NAAS (in particular, M. Shevchenko [3] and N. Liashenko [2]) concerning to the prospects of transfer of innovative varietal resources and technical and technological achievements, there have been predicted the parameters of grain production in the Steppe zone of Ukraine and its resource provision for the period up to 2030.

Forecast calculations have been performed for two main models of development of the grain sector. The first model is based on maintaining the achieved size of the grain acreage and its minimum expansion to the level of 6900 thousand hectares. It is envisaged that with the expected deterioration of the economic situation in the country, the grain sector will operate in conditions of limited opportunities to increase a consumption of production resources and restrain the rate of implementation of innovative achievements. Here, with a projected average yield of $3.82 \mathrm{t} / \mathrm{ha}$, it is possible to obtain 26.3 million tons of grain per year. The second model is less likely for the nearest years, but in the longer term an improvement of material and technical base of agricultural formations and a widespread introduction of advanced technologies will allow in conditions of expanding harvested areas of grain crops to 7350 thousand hectares to expect an increase in grain yields in the Steppe regions to the level of $4.77 \mathrm{t} / \mathrm{ha}$ and the size of annual grain production to 35.0 million tons (Table 5).

Based on the current price situation in April-May 2020 in the market of material and technical resources, the necessity for such resources sufficient to ensure the forecast parameters of grain production has been calculated. Thus, in conditions of limited access to resources for a maintenance of technological requirements, the need for production resources per hectare will range from 8.7 thousand UAH/ha in the cultivation of other spring cereals (oats, buckwheat, millet, sorghum, etc.) to 15.1 thousand UAH/ha in the production of maize, and the average level for the group of grain crops will be 11.9 thousand UAH per hectare of sown area. Under favorable weather and climatic conditions, this level of expenditures will be sufficient to ensure the production of 3.82 tons of grain per 1 hectare. In general, for the production of 26.3 million tons of grain, the estimated cost of funds will be 82.39 billion $\mathrm{UAH}$, of which mechanized work (such items as wages, fuel and lubricants, amortization and outlays on repair of technical means, etc.) will account for $32.0 \%$, fertilizers $-24.7 \%$, and plant protection means $-8.9 \%$.

The introduction of scientifically ground technologies aimed at increasing the realization of yield potential of cultivated crops will require appropriate expenditures of money-material and labor resources. Thus, for grain production in the Steppe zone in the size of 35.0 million tons there will be needed 97.93 billion UAH, including 31.82 billion UAH for mechanized works $(32.5 \%)$. A significant share will be occupied by the outlays that can be considered as elements of intensification, in particular, fertilizers in the amount of 26.22 billion UAH $(26.8 \%)$ and plant protection means -7.8 billion UAH ( $8.0 \%)$. 





Assessing the economic efficiency of grain production in the Steppe zone of Ukraine in the future, it should be noted that on conditions of compliance with the prescribed technological order for grain crops cultivation and effective implementation of plans of innovations transfer, this sector will be profitable. This is evidenced by the calculated forecast indicators of grain sales efficiency shown in the Table 6.

Table 6

\section{Indicators of efficiency of grain sales in the agricultural enterprises} of the Steppe zone of Ukraine for the perspective

\begin{tabular}{|l|c|c|c|c|c|c|c|c|}
\hline \multirow{2}{*}{ Crops } & \multirow{2}{*}{\begin{tabular}{c} 
Structure $\begin{array}{c}\text { of } \\
\text { commodity } \\
\text { output, \% }\end{array}$ \\
\cline { 2 - 9 }
\end{tabular}} & \multicolumn{2}{|c|}{ per 1 hectare } & \multicolumn{2}{c|}{ per 1 ton } & \multicolumn{2}{c|}{$\begin{array}{c}\text { Conditional profit (UAH) } \\
\text { profitability, } \\
\text { \% }\end{array}$} \\
\hline Grain crops total & 100 & 100 & 5669.8 & 8657.9 & 1485.50 & 1816.66 & 43.6 & 59.1 \\
\hline $\begin{array}{l}\text { including: } \\
\text { winter wheat }\end{array}$ & 51.3 & 48.7 & 6769.3 & 10172.6 & 1809.41 & 2152.70 & 52.3 & 69.0 \\
\hline $\begin{array}{l}\text { other winter grain } \\
\text { crops }\end{array}$ & 10.7 & 10.8 & 3323.2 & 6166.1 & 923.12 & 1355.19 & 25.7 & 42.8 \\
\hline spring barley & 9.6 & 9.7 & 2310.2 & 4394.8 & 757.46 & 1132.67 & 22.9 & 38.7 \\
\hline grain maize & 22.2 & 23.2 & 7313.1 & 10169.1 & 1379.82 & 1609.03 & 44.2 & 55.7 \\
\hline grain legume & 3.6 & 4.3 & 5910.8 & 9351.2 & 2073.95 & 2597.55 & 47.6 & 67.8 \\
\hline $\begin{array}{l}\text { other spring grain } \\
\text { crops }\end{array}$ & 2.6 & 3.3 & 4223.0 & 6559.3 & 1702.84 & 2102.35 & 45.1 & 62.2 \\
\hline
\end{tabular}

Note: $1^{*}-$ at the forecasted level of grain production of 26.3 million tons, $2^{*}$ - the forecasted level of grain production of 35.0 million tons.

Forecast calculations show that in the current price situation in the domestic grain market, the expected revenue from the sale of grain products will be 128.9 billion UAH for the first model of grain production (26.3 million tons) and 171.4 billion UAH for the second model (35.0 million tons). This will allow receiving 39.1 and 63.6 billion UAH of profit appropriately. In the structure of commodity output, winter wheat will occupy the largest share (51.3 and $48.7 \%$, respectively).

The overall economic effect in the long term will depend on a conjuncture of the grain market and the effectiveness of the application of the levers of its state regulation. The data of Table 6 show that grain production in the Steppe zone in the size of 26.3 million tons will be effective at the level of profitability of $43.6 \%$ and profit indicator of a hectare of land of 5669.8 UAH/ha.

The further rising grain yield to $4.77 \mathrm{t} / \mathrm{ha}$, increasing the size of grain production to 35.0 million tons and achieving profitability indicator at the level of $59.1 \%$ is possible on the conditions of improving financial status of agricultural producers and rising a degree of their readiness to implement the innovative elaborations offered by agricultural science. With a favorable price 
situation, it is possible to increase the level of profitability of grain production to 65-70\%, which will provide sufficient opportunities for expanded reproduction of production, implementation of environmental measures and development of human capacity of domestic agricultural formations.

\section{Conclusions}

On the basis of the results of statistical and economic analysis, it have been established that despite the increase in gross grain harvest to 21.4-25.0 million tons for 2015-2019, the level of efficiency of grain production in the Steppe zone of Ukraine is insufficient for expanded reproduction of production and competitive functioning of the sector. A possible decline in the gross grain harvest due to the expected deterioration in the financial status of agricultural formations has been forecasted.

A package of measures to increase the efficiency of the grain sector of the Steppe zone of Ukraine has been determined. The structure of grain crops acreage, the parameters of harvested areas and grain crops yields for two projected levels of production of 26.3 and 35.0 million tons have been grounded. On the basis of the normative expenditures determined for technologies with different levels of resource provision, there have been calculated the necessity for production resources that is 82.39 and 97.93 billion UAH respectively according to the calculations. Forecast indicators of profitability of grain production under conditions of preservation of the current price situation on the grain market will achieve the level of 43.6 and $59.1 \%$ accordingly. This will allow to receive on the average 5.7 and 8.7 thousand UAH of conditional profit per 1 hectare. With a favorable price situation, it is considered possible to increase the level of profitability of grain production to $65-70 \%$.

Transformational processes in the economy, development of the research on elaboration of newest agricultural technologies and selection of highyielding varieties (hybrids) in the conditions of climate changes, increasing the rates of transfer of innovations, changes in technical and technological support of the grain sector, improving the concept of land resources management will require the further author economic research on grounding parameters of grain production and its efficiency in regions and naturaleconomic zones of Ukraine.

Scientific elaboration is expedient for use in planning and economic work of bodies of the state and regional management of agro-industrial complex, and also in activity of scientific institutions and separate researchers working on the decision of a grain problem. It is an important information resource for substantiating the directions of development of the grain sector of Ukraine, increasing the gross grain harvests and improving the efficiency of grain production. 


\section{References:}

1. Horpinchenko K. N., Prudnikov A. H. (2012) Kontseptsiya innovatsionnogo razvitiya zernovogo proizvodstva regiona [The concept of innovative development of grain production in the region]. Ekonomicheskie issledovaniya (electronic journal), No. 4(12) / Available at: http://www.erce.ru/internet-magazine/magazine/32/498/ (accessed 12 June 2020).

2. Rybka V. S., Liashenko N. O. (2017) Naukovo obgruntovana stratehiia efektyvnoho rozvytku vyrobnytstva zerna kukurudzy $v$ Prydniprovskomu rehioni [Scientifically substantiated strategy of effective development of corn grain production in the Dnieper region]. Eksklyuzivnyie tehnologii, No. 5-6 (50), pp. 8-14.

3. Maslov H. H., Hejfec A. B. (2016) Tekhnicheskoe sovershenstvovanie tekhnologij proizvodstva zerna [Technical improvement of grain production technologies]. Nauchnyj zhurnal KubGAU, No. 115(01), p. 1-22.

4. Maslov H. H., Hejfec A. B. (2016) Tekhnologicheskoe sovershenstvovanie proizvodstva zerna primeneniem mashin [Technological improvement of grain production by using machines]. Nauchnyj zhurnal KubGAU, No. 115(01), p. 23-40.

5. Sabluk P. T., Mazorenko D. I., Mazniev H. Ye. (2008) Tekhnolohii vyroshchuvannia zernovykh i tekhnichnykh kultur v umovakh Lisostepu Ukrainy [Technologies for growing cereals and industrial crops in the Forest-Steppe conditions of Ukraine]. Kyiv: NNTs IAE. (in Ukrainian)

6. Sabluk, P. T., Melnyk, Yu. F., Zubets, M. V, Mesel-Veseliak, V. Ya. et al. (2008) Normatyvna sobivartist' ta tsiny na sil's'kohospodars'ku produktsiiu [Normative cost and prices for agricultural products]. Tsinoutvorennia ta normatyvni vytraty $v$ sil's'komu hospodarstvi (teoriia, metodolohiia, praktyka) [Pricing and normative expenses in agriculture (theory, methodology, practice)], vol. 2. Kyiv: NNTs IAE, pp. 8-38.

7. Shpychak O. M., Hanusenko Yu. A. et al. (2006) Normatyvni vytraty, tsiny, balansy silskohospodarskoi produktsii v Ukraini ta krainakh svitu [Normative expenditures, prices, balances of agricultural products in Ukraine and countries of the world]. Kyiv: NNTs IAE. (in Ukrainian)

8. Cherenkov, A.V., Rybka, V.S., Kompaniets V. O., et al. (2017) Нормативнометодичний довідник по обгрунтуванню виробничих затрат в зерновому господарстві Степу України [Normative-methodical reference book on substantiation of production costs in the grain economy of the Steppe of Ukraine]. Dnipro: DU Instytut zernovykh kultur NAAN Ukrainy. (in Ukrainian)

9. Cherchel V. Yu., Shevchenko M. S. (2020) Ahroresursy i naukove modeliuvannia vyrobnytstva $100 \mathrm{mln}$ tonn zerna [Agricultural resources and scientific modeling production of 100 million tons of grain]. Zernovi kultury, vol. 4, No. 1, pp. 53-63.

10. Dushko M. V. (2007) Ahroekonomichne obgruntuvannia kontseptsii tekhnolohii vyroshchuvannia silskohospodarskykh kultur [Agro-economic substantiation of concepts of technologies of crops cultivation]. Ekonomika APK, No. 4, pp. 39-45.

11. Kompaniets V. O. (2008) Ekoloho-ekonomichni aspekty ratsionalnoho vykorystannia zemelnykh resursiv $v$ umovakh pivnichnoho Stepu Ukrainy [Ecological and economic aspects of rational use of land resources in the conditions of the northern Steppe of Ukraine]. Naukovyi Visnyk Natsionalnoho ahrarnoho universytetu. No. 120, pp. 301-306.

12. Zubets M. V. (2010) Naukovi osnovy ahropromyslovoho vyrobnytstva v zoni Stepu Ukrainy [Scientific bases of agro-industrial production in the Steppe zone of Ukraine]. Kyiv: Ahrarna nauka. (in Ukrainian) 